\title{
Repellency of Dettol, a Commercial Cleaning Product, Against Adult American Cockroaches Periplaneta americana (L.)
}

\author{
*M. M. Yahaya and A. Y. Clement \\ Department of Biological Sciences \\ Usmanu Danfodiyo University, Sokoto. \\ [*Corresponding Author: mmyahayakhad@yahoo.co.uk]
}

\begin{abstract}
Dettol, a commercial cleaning product was tested for its repellent action against adults of Periplaneta americana (L.). Experimental cage was constructed with pieces of polypropylene plastic material to have a finished form measuring $30 \times 30 \times 60 \mathrm{~cm}$. Two cardboard shelters (for each trial) were assembled each $10 \mathrm{~cm}$ square by size with an opening of $1.5 \times 1.5 \mathrm{~cm}$ to allow for free passage. One of the shelters was treated with undiluted Dettol, the other with water (control) prior to placement in the cage. Twenty five adult roaches were released in the cage also provided with water and $50 \mathrm{~g}$ dog biscuit at each trial. The cage was placed close to the sunlight by midday over seven days observation period and the number of roaches in and close to the shelters were recorded three times by 30 minutes interval. Similar procedure was used when applying 1:37 and 1:74 dilutions of the product. A highest mean repellency $(0.00 \pm 0.00)$ was observed in the treated shelter (TS) with undiluted concentration while the least $(13.33 \pm 1.15)$ was in the control shelter (CS). Similarly, repellency was extended close to the treated shelter (CTS) than close to the control shelter (CCS). However, repellency was observed to be indirectly proportional to both concentration and exposure time. The active ingredient responsible for repelling the roaches in Dettol is discussed.
\end{abstract}

Keywords: Repellency, Periplaneta americana, Dettol

\section{INTRODUCTION}

Cockroaches are the most abundant and obnoxious non-biting insect pest in residential buildings, hospitals, hostels and restaurants (Hahn, 2003; Kutrup, 2003; Mba and Kelly, 2003). They feed indiscriminately on human food and sewage and so have copious opportunity to disseminate human pathogens. When cockroaches run over food, they may leave filth or oily liquid that has offensive and sickening odour which ruin food or render it unacceptable (Brenner et al., 1987). Pathogenic bacteria including Salmonella spp, Shigella spp, Campylobacter spp, Pseudomonas aeruginosa and Klebsiella pneumoniae have been isolated from cockroaches (Cotton et al., 2000). These insects have been epidemiologically involved in toxoplasmosis, giardiasis, sarcocystosis, and intestinal amoebiasis (Smith and Frenkel, 1978, Majewska, 1986, Pai et al., 2003). Similarly, exposure to cockroach antigens may play an important role in asthma-related health problems (Arruda, 2005). Recent studies strongly associated the presence of cockroaches and increase in the severity of asthma symptoms in individuals who are sensitive to cockroach allergins (Alph et al., 2001; Arlian, 2002; Miller and Peter, 2004).

There is unprecedented increase in cockroach population in public places and residential apartments in North America (Rauh et al., 2002), Asia (Dong-kyu, 1995; Ghosh and Gayen, 2006), the Middle East (Kutrup, 2003) and Australia (Miller and Peter, 2004). In Nigeria, the risk to human health arising from cockroach infestation has hitherto been underestimated considering the dearth of entomological and epidemiological information available (Omudu and Eyumah, 2008). However, greater efforts have been made over the years to control cockroaches by using several control measures ranging from the use of insecticidal sprays, dusts and powders, baits and traps, which are either directed on the eggs, nymphs or the adult cockroaches. The use of synthetic insecticides for controlling insect pests has been discouraged for various reasons. Some alternative measures like using bio-friendly repellents against cockroaches are highly sought for. In the present study authors have examined the effect of Dettol, a 
commercial cleaning product on adults of American cockroach, Periplaneta americana.

\section{MATERIALS AND METHODS}

Adult American cockroaches, Periplaneta americana (L.) were collected from toilets and bathrooms of human dwelling. The three (3) batches of twenty five (25) cockroaches collected regardless of sex were acclimated in the laboratory for a week in boxes before used in the experiment. Two shelters each measuring $10 \times 10 \times 10 \mathrm{~cm}$ used in each separate experiment ware built using cardboard paper with an opening of $1.5 \times 1.5 \mathrm{~cm}$ to allow for free movement of the cockroaches in and out of the shelters. One of these was designated as a treated shelter (TS) whiles the other a control (CS). The TS was treated inside with $5 \mathrm{~mL}$ spray of the undiluted product (Dettol) using a small hand sprayer whiles the CS with equal volume of water. Both were allowed to dry for few minutes under sunlight and then were placed in a constructed polypropylene plastic cage measuring $30 \times 30 \times 60 \mathrm{~cm}$ with a wire mesh at the top.

Twenty five adult cockroaches were released in the cage provided with $50 \mathrm{~g}$ dog biscuit and water placed at the center of the cage between the two shelters to serve as food. The cage was moved close to the sunlight each day by midday in order to encourage the cockroaches to hide in the preferred shelter through the duration of the experiment. The number of cockroaches in the TS as well as the CS and close to each (close to treated shelter-CTS, close to control shelter-CCS), were recorded three times daily by 30 minutes interval. Two separate dilutions of the same product; 1:37 and 1:74 were also tested against the roaches using the above procedure. For the 1:37, one capful $(27 \mathrm{~mL})$ of the product was diluted in a liter of water to attain the dilution as recommended by the manufacturer for household cleaning. Half capful $\mathrm{L}$ of water was used in the case of 1:74 dilutions also recommended for personal hygiene. Number of days for significant repellency ware determined by using Analysis of Variance (ANOVA) and mean separation was based on using LSD at 5\%. Moreover, percent repellency was calculated using the following formula:

$$
100-[100 \times\{\mathrm{Nt} /(\mathrm{Nt}+\mathrm{Nc})\}]
$$

Where Nt is the number of cockroaches in the treated shelter and $\mathrm{Nc}$ in the control shelter. (Steltenkamp et al., 1992)

\section{RESULTS}

Undiluted product: The repellent effect of the undiluted product on American cockroaches over the duration of observation was summarized in Table 1.

\section{Table 1: Repellency of undiluted Dettol on P. americana}

\begin{tabular}{lccccccc}
\hline $\begin{array}{c}\text { Treatment } \\
\text { groups } \\
\text { (shelter) }\end{array}$ & \multicolumn{7}{c}{ Average number of cockroaches in successive days \pm SD (Repellency in per cent) } \\
\cline { 2 - 8 } & 1 & 2 & 3 & 4 & 5 & 6 & 7 \\
\hline TS & $0.00 \mathrm{a} \pm 0.0$ & $0.00 \mathrm{a} \pm 0.0$ & $0.00 \mathrm{a} \pm 0.00$ & $0.00 \mathrm{a} \pm 0.00$ & $0.00 \mathrm{a} \pm 0.00$ & $0.00 \mathrm{a} \pm 0.00$ & $0.67 \mathrm{a} \pm 1.2$ \\
& $(100)$ & $(100)$ & $(100)$ & $(100)$ & $(100)$ & $(100)$ & $(93.7)$ \\
CTS & $2.67 \mathrm{a} \pm 0.6$ & $2.00 \mathrm{a} \pm 0.0$ & $3.33 \mathrm{~b} \pm 1.5$ & $3.00 \mathrm{~b} \pm 1.0$ & $3.00 \mathrm{~b} \pm 1.0$ & $1.67 \mathrm{a} \pm 0.6$ & $4.00 \mathrm{~b} \pm 1.0$ \\
& $(77.1)$ & $(82.9)$ & $(76.8)$ & $(67.8)$ & $(75.0)$ & $(84.3)$ & $(73.9)$ \\
CCS & $9.00 \mathrm{~b} \pm 1.0$ & $11.67 \mathrm{~b} \pm 1.5$ & $11.00 \mathrm{c} \pm 1.7$ & $6.33 \mathrm{c} \pm 1.2$ & $9.00 \mathrm{c} \pm 1.0$ & $9.00 \mathrm{~b} \pm 2.0$ & $11.33 \mathrm{c} \pm 0.6$ \\
& $(22.9)$ & $(17.1)$ & $(23.2)$ & $(32.2)$ & $(25.0)$ & $(15.7)$ & $(26.1)$ \\
CS & $13.3 \mathrm{~b} \pm 1.2$ & $11.33 \mathrm{~b} \pm 1.5$ & $10.67 \mathrm{c} \pm 0.6$ & $15.67 \mathrm{~d} \pm 0.6$ & $13.00 \mathrm{~d} \pm 1.7$ & $14.33 \mathrm{c} \pm 2.1$ & $10.00 \mathrm{c} \pm 1.0$ \\
& $(0.0)$ & $(0.0)$ & $(0.0)$ & $(0.0)$ & $(0.0)$ & $(0.0)$ & $(6.3)$ \\
LSD & 5.17 & 2.03 & 2.43 & 1.54 & 2.11 & 3.15 & 1.80 \\
\hline
\end{tabular}

Means followed by the same letter are not significantly different $(\mathrm{p}<0.05)$ CS: control shelter, TS: treated shelter, CCS: close to control shelter, CTS: close to treated shelter

There was complete repellency for six days on the roaches in the treated shelter (TS). On day seven few cockroaches with a mean number of $0.67 \pm 1.2(93.7 \%$ repellency) were observed in the shelter indicating that the effect has began to lessened. More than half of the cockroaches ware residing almost always within the control shelter (CS), but with fluctuating means between $15.67 \pm 0.6$ to $10.00 \pm 1.0$ (zero percent$6.3 \%$ repellency). There was a daily high significant difference $(\mathrm{P}<0.05)$ for repellency in favor of TS. This effect was extended close 
to the treated shelter (CTS) than close to control shelter (CCS). Moreover, the means of cockroaches within CTS, though fluctuate also (between the seven days of observation), that is from $1.67 \pm 0.6$ to $4.00 \pm 1.0$ ( $84.3 \%$ - $73.9 \%$ repellency), were statistically significant $(\mathrm{P}<0.05)$ in every respect by comparison with $6.33 \pm 1.2 \quad(32.2 \%$ repellency) to $9.00 \pm 2.0$ (15.7\% repellency) obtained within CCS.

1:37 dilution: Application of the test product in diluted form, (recommended for household cleaning) has also resulted in high repellency on the cockroaches in both TS and CTS (Table 2). Although, lesser mean numbers of cockroaches were recorded in the TS for up to four days ranging between $1.00 \pm 1.0$ to $1.33 \pm 0.6$ (94.1\%-92.3\% repellency), the values did not differ significantly $(\mathrm{P}<0.05)$ with those obtained around CTS where repellency was between $83.3 \%$ in the first two days and $62.5 \%$ on the last. For the CS and CCS, the mean value ranges of cockroaches present were $11.67 \pm 1.5$ ( $16.6 \%$ repellency) to $17.00 \pm 1.0$ $(5.6 \%$ repellency) and $4.67 \pm 0.6 \quad(26.3 \%$ repellency) to $8.00 \pm 1.0$ ( $27.3 \%$ repellency) respectively. These values were still high and not significant $(\mathrm{P}>0.05)$ in reference to TS since the higher the mean the lesser the repellency (Table 2).

Table 2: Repellency of diluted Dettol (1:37) on P. americana

\begin{tabular}{lccccccc}
\hline $\begin{array}{c}\text { Treatment } \\
\text { groups } \\
\text { (shelter) }\end{array}$ & \multicolumn{7}{c}{ Average number of cockroaches in successive days \pm SD (Repellency in per cent) } \\
\cline { 2 - 8 } & 1 & 2 & 3 & 4 & 5 & 6 & 7 \\
\hline TS & $1.00 \mathrm{a} \pm 1.0$ & $1.00 \mathrm{a} \pm 1.0$ & $2.00 \mathrm{a} \pm 0.00$ & $1.33 \mathrm{a} \pm 0.6$ & $2.60 \mathrm{a} \pm 1.2$ & $2.33 \mathrm{a} \pm 1.2$ & $3.00 \mathrm{a} \pm 0.0$ \\
& $(94.1)$ & $(94.4)$ & $(89.3)$ & $(92.3)$ & $(84.0)$ & $(83.4)$ & $(82.4)$ \\
CTS & $1.67 \mathrm{a} \pm 0.6$ & $1.00 \mathrm{a} \pm 0.0$ & $1.67 \mathrm{a} \pm 0.6$ & $2.00 \mathrm{a} \pm 1.0$ & $2.67 \mathrm{a} \pm 1.2$ & $3.00 \mathrm{a} \pm 0.0$ & $3.00 \mathrm{a} \pm 1.0$ \\
& $(79.1)$ & $(83.3)$ & $(73.7)$ & $(73.9)$ & $(68.0)$ & $(72.7)$ & $(62.5)$ \\
CCS & $6.33 \mathrm{~b} \pm 1.2$ & $5.00 \mathrm{~b} \pm 1.7$ & $4.67 \mathrm{~b} \pm 0.6$ & $5.67 \mathrm{~b} \pm 0.6$ & $5.67 \mathrm{~b} \pm 2.3$ & $8.00 \mathrm{~b} \pm 1.0$ & $5.00 \mathrm{~b} \pm 1.0$ \\
& $(20.9)$ & $(16.3)$ & $(26.3)$ & $(26.1)$ & $(32.0)$ & $(27.3)$ & $(37.5)$ \\
$\mathrm{CS}$ & $16.00 \mathrm{c} \pm 1.0$ & $17.00 \mathrm{c} \pm 1.0$ & $16.67 \mathrm{c} \pm 1.2$ & $16.00 \mathrm{c} \pm 1.0$ & $14.00 \mathrm{~b} \pm 2.0$ & $11.67 \mathrm{c} \pm 1.5$ & $14.00 \mathrm{c} \pm 1.0$ \\
& $(5.9)$ & $(5.6)$ & $(10.7)$ & $(7.7)$ & $(16.0)$ & $(16.6)$ & $(17.6)$ \\
LSD & 1.80 & 2.11 & 1.30 & 1.22 & 3.26 & 2.03 & 1.33 \\
\hline
\end{tabular}

Means followed by the same letter are not significantly different $(\mathrm{p}<0.05)$ CS: control shelter, TS: treated shelter, CCS: close to control shelter, CTS: close to treated shelter

Table 3: Repellency of diluted Dettol (1:74) on P. americana

\begin{tabular}{|c|c|c|c|c|c|c|c|}
\hline \multirow{2}{*}{$\begin{array}{c}\text { Treatment } \\
\text { groups } \\
\text { (shelter) }\end{array}$} & \multicolumn{7}{|c|}{ Average number of cockroaches in successive days $\pm \mathrm{SD}$ (Repellency in per cent) } \\
\hline & 1 & 2 & 3 & 4 & 5 & 6 & 7 \\
\hline TS & $\begin{array}{c}1.67 \mathrm{a} \pm 0.6 \\
(85.7)\end{array}$ & $\begin{array}{c}2.67 \mathrm{a} \pm 0.6 \\
(83.0)\end{array}$ & $\begin{array}{c}3.33 \mathrm{a} \pm 0.6 \\
(73.0)\end{array}$ & $\begin{array}{c}3.33 \mathrm{a} \pm 0.6 \\
(74.4)\end{array}$ & $\begin{array}{c}3.33 \mathrm{a} \pm 1.5 \\
(72.3)\end{array}$ & $\begin{array}{c}4.33 \mathrm{ab} \pm 0.6 \\
(75.0)\end{array}$ & $\begin{array}{c}4.67 a \pm 1.5 \\
(73.6)\end{array}$ \\
\hline CTS & $\begin{array}{c}3.38 \mathrm{a} \pm 0.6 \\
(74.7)\end{array}$ & $\begin{array}{c}3.67 \mathrm{a} \pm 0.0 \\
\quad(67.8)\end{array}$ & $\begin{array}{c}3.67 \mathrm{a} \pm 1.5 \\
(71.0)\end{array}$ & $\begin{array}{c}4.00 \mathrm{a} \pm 1.0 \\
(66.7)\end{array}$ & $\begin{array}{c}4.33 \mathrm{a} \pm 1.2 \\
\quad(66.7)\end{array}$ & $\begin{array}{c}2.67 a \pm 1.2 \\
(65.2)\end{array}$ & $\begin{array}{c}4.00 \mathrm{a} \pm 1.0 \\
(45.4)\end{array}$ \\
\hline $\mathrm{CCS}$ & $\begin{array}{c}10.00 \mathrm{~b} \pm 1.7 \\
(25.3)\end{array}$ & $\begin{array}{c}6.33 a \pm 3.8 \\
(32.2)\end{array}$ & $\begin{array}{c}9.00 \mathrm{~b} \pm 3.5 \\
(29.0)\end{array}$ & $\begin{array}{c}8.00 \mathrm{~b} \pm 1.7 \\
(33.3)\end{array}$ & $\begin{array}{c}8.67 b \pm 1.5 \\
\quad(33.3)\end{array}$ & $\begin{array}{c}5.00 \mathrm{~b} \pm 1.7 \\
(34.8)\end{array}$ & $\begin{array}{c}3.33 \mathrm{a} \pm 2.5 \\
(54.6)\end{array}$ \\
\hline CS & $\begin{array}{c}10.00 \mathrm{~b} \pm 2.0 \\
(14.3)\end{array}$ & $\begin{array}{c}13.00 b \pm 3 . \\
5 \\
(17.0)\end{array}$ & $\begin{array}{c}9.00 \mathrm{~b} \pm 2.0 \\
(27.0)\end{array}$ & $\begin{array}{c}9.67 b \pm 1.5 \\
(25.6)\end{array}$ & $\begin{array}{c}8.67 b \pm 1.7 \\
\quad(27.7)\end{array}$ & $\begin{array}{c}13.00 \mathrm{c} \pm 1.0 \\
(25.0)\end{array}$ & $\begin{array}{c}13.00 \mathrm{~b} \pm 0.0 \\
(26.4)\end{array}$ \\
\hline LSD & 2.61 & 4.86 & 4.07 & 3.67 & 2.82 & 2.24 & 2.93 \\
\hline
\end{tabular}

Means followed by the same letter are not significantly different $(\mathrm{p}<0.05)$ CS: control shelter, TS: treated shelter, CCS: close to control shelter, CTS: close to treated shelter

1:74 dilution: When the test product was further diluted twice (following the manufacturers recommendation for personal hygiene), similar pattern of observations were made. TS and CTS maintained high repellency with no significant differences between the two locations, whereas CS and CCS remained steadily preferred by the roaches and the mean values recorded were not significant for relatively whole seven days of observations (Table 3). Fig. 1-3 represents daily percentages of repellency against the roaches. 


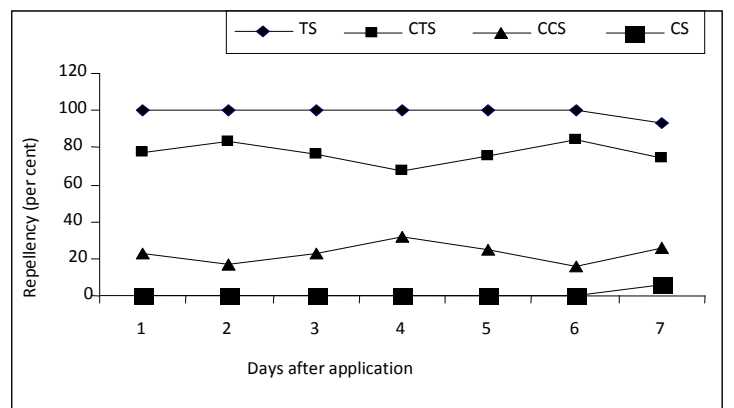

Fig. 1: Repellency of undiluted Dettol on $P$. americana

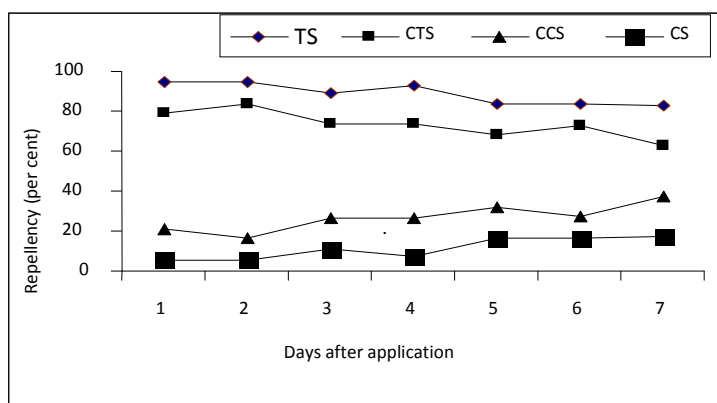

Fig. 2: Repellency of 1:37 dilution of Dettol on P. americana

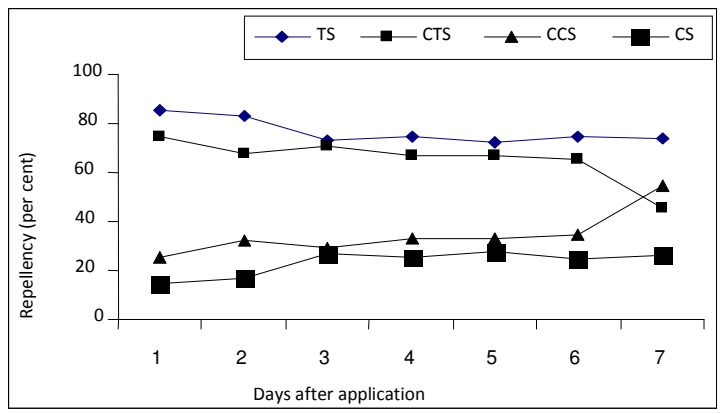

Fig. 3: Repellency of 1:74 dilution of Dettol on P. americana

\section{DISCUSSION}

The results of the present study revealed that Dettol, a commercial cleaning product drive away cockroaches. This was indicated by the product yielding significantly higher repellency within both TS and CTS in comparison to CS and CCS. Complete repellency (100\%) was achieved for six days in the TS while more than $70 \%$ in the CTS with undiluted application of the product. Similar observations indicating $90 \%$ repellency for three days were reported by Ho and Goh (1996) using Ajax Expel (another cleaning product) against female American cockroaches. Methyl neodecanamide which is the main ingredient in Ajax Expel had earlier on been shown to be active repellent on cockroaches (Steltenkamp et al., 1992). It was also noted that repellency of Dettol decreased with dilution and time. This fact remained true for relatively all active compounds since physical forces such as temperature, light; humidity, air etc. can aid rapid diffusion or decomposition. Application of the two separate dilutions of the product $(1: 37$ and $1: 74)$ were also significant $(\mathrm{P}<0.05)$ for repelling the cockroaches in TS $(90-70 \%$ repellency) and CTS (70-40\% repellency) over the seven days period of observation. In the former (1:37 dilution) repellency was higher than $80 \%$ for three days as also reported by Ho and Goh (1996) with dilution of 1:8 of their test product. However, repellency of $70 \%$ for 5.7 days reported by Connors (1994) when working with German cockroaches is at par with that observed in the CTS though with fluctuations between days.

One of the apparent reasons for attaining high repellency in this study might be the modification of the shelter set-up from $7.6 \mathrm{~cm}$ square (Ho and Goh, 1996) to $10 \mathrm{~cm}$ square. American cockroaches are larger than most other common cockroaches, more of the number would be presumed occupying the preferred shelter since the space was conveniently enough for the twenty five American cockroaches. Therefore, there can be no question of certain number of unaccommodated cockroaches outside that was unaccounted for. Likewise, chloroxylenol in Dettol (active principle) which might also be responsible for repellency could be more stable in the air than methyl neodecanamide to exploit longer period of repellency. Moreover, American cockroaches may be simply more predisposed to the compounds in Dettol than to those of Ajax Expel. Reports have shown that, cockroaches are biochemically resistant to pyrethroid in some countries (Atkinson et al., 1991., Jensen, 1993). Where baits have been used over extended periods against other animals such as rodents baits shyness has been noted (Meeham, 1984). Incipient behavioural resistance has been noted with baits (Silverman and Bieman, 1993) and cockroaches certainly can detect and may be repelled by some insecticides (Ebeling et al., 1967). Thus, with the recent urge for using less insecticides, combination or alternating use of pyrethroid, 
Dettol and possibly other cleaning products with comparable potentials, present possibilities of managing both behavioural and biochemical resistance. Further laboratory and field studies should investigate the potential of these combinations.

\section{REFERENCES}

Alph, B. H., Grant, E. N., Rao, V. and Moy, J. N. (2001). Cockroach allergy appears early in life in inner-city children with recurrent wheezing. Annals of Allergy Asthma Immunology, 86 (1): 51-54

Arlian, J. (2002). The risk of human health from cockroach infestations. Journal of Environmental Health Research, 8 (1): 23-29

Arruda, L. K. (2005). Cockroach allergens. Current Allergy Asthma Report, 5: 41116

Atkinson, T. H. R. W., Wadleigh, P. G., Koehler, U. and Patterson, R. S. (1991). Pyrethroid resistance and synergism in a field strain of the German cockroach (Dictyoptera: Blattellidae). Journal of Economic Entomology, 84: 1247-150

Brenner, R. J., Koehler, P and Patterson, R. S. (1987). Health Implications of Cockroach Infestation. Infestation in Medicine, 4 (8): 349-355

Connors, T. F. (1994). Achieving repellency benefits in a cleaning product. Paper Presented at the $5^{\text {th }}$ European Congress of Entomology. York, U. K., 29 August - 2 September, 1994.

Cotton, M. F., Wasserman, E., Pieper, C. H., Van Tubberg, D., Camphell, G., Fang, F. C. and Barnes, J. (2000). Invasive disease due to extended spectrum betalactamase-producing Klebsiella pneumonie in a neonatal unit: the possible role of cockroaches. Journal of Hospital Infection, 44:13-17

Dong-Kyu, L. (1995). Distribution and seasonal abundance of cockroaches (Blattellidae, Blattidae and Blatteria) in urban General hospital. Korean Journal of Entomology, 5: 57 - 67

Ebeling, W., Reierson, D. A. and Wagner, R. E. (1967). Influence of repellency on the efficacy of blatticides. II. Field experiments with German cockroaches with notes on three other species. Journal of Economic Entomology, 61: 751-761
Ghosh, J. and Gayen, A. (2006). The protozoan fauna living in the digestive system of Periplaneta americana in Kolkata, West Bengal, India. Journal of Parasitic Diseases, 30 (1):76-80

Hahn, J. (2003). Cockroaches in your home. University of North Carolina Public Health Pest Management Publication. Raleigh, North Carolina U. S. A.34p

Ho, S. H. and Goh, P. M. (1996). Repellency of Ajax Expel against Periplaneta americana (L.). International Pest Control, 38: 92-94.

Jensen, K. M. V. (1993). Insecticide resistance in Blattellla germanica (L.) Dictyoptera: Blattellidae from wood producing establishments in Denmark. In Wildney, K. B. and Robinson, W. H. Proceedings of first International Conference on Insect Pest in the Urban Environment. Exeter: Wheatons, 135-139

Kutrup, B. (2003). Cockroach infestation in some hospitals in Trabzon, Turkey. Turk Journal of Zoology, 27: 73-77

Majewska, A. C. (1986). Verification of the theory of the role of synanthropic insects in the transmission of intestinal protozoa. Przegl Epidemiology, 40: 300-303

Mba, C. E. and Kelly, D. (2003). Preliminary trials of environment friendly cockroach traps in Zaria northern Nigeria. Journal of Tropical Biosciences, 3: 7-10

Meehan, A. P. (1984). Rats and mice, their biology and control. $1^{\text {st }}$ edition. Sussex: Rentokil, 65-71 pp.

Miller, P. and Peter, B. (2004). Overview of the public health implications of cockroach and their management. New South Wales Public Health Bulletin, 15 (11-12): 208-211

Omudu, E. A. and Eyumah, A. O. (2008). A Survey of the knowledge, Attitude and Perception of Cockroach Infestation and its Public Health Implications in Makurdi, Nigeria. Nigerian Journal of Entomology, 25: 60-66.

Pai, H. H., Ko, Y. C. and Chen, E. R. (2003). Cockroaches (Periplaneta americana and Blattella germanica) as potential mechanical disseminators of Entamoeba histolytica. Acta Tropica, 84: 355-359

Rauh, V. A., Chew, G. L. and Garfinkel, R. S. (2002). Deteriorated housing contributes to high cockroach allergen levels in inner 
city households. Environmental Health Perspective Supplements, II (2): 37-42.

Silverman, J. and Bieman, D. N. (1993). Glucose aversion in the German cockroach, Blattella germanica. Journal of Insect physiology, 39: 925-933.

Smith, D. D. and Frenkel, J. K. (1978). Cockroaches as Vectors of Sarcocystis muris and of other occcidia in the laboratory. Journal of Parasitology, 64: 315-319

Steltenkamp, R. J., Hamilton, R. L., Cooper, R. A. and Schal, C. (1992). Alkyl and aryl neoalkanamides: highly effective insect repellents. Journal of Medical Entomology, 29: 141 - 149. 